Columbia Law School

Scholarship Archive

2015

An Analysis of Senator McConnell's Letter Urging States Not to Comply with EPA's Clean Power Plan

Daniel Selmi

Follow this and additional works at: https://scholarship.law.columbia.edu/sabin_climate_change

Part of the Environmental Law Commons 


\title{
An Analysis of Senator McConnell's Letter Urging States Not to Comply with EPA's Clean Power Plan
}

\author{
By Daniel Selmi \\ April 2015
}

Executive Summary: On numerous occasions Senator Mitchell McConnell, the Senate Majority Leader, has attacked the upcoming Clean Power Plan regulations that the Environmental Protection Agency (EPA) is scheduled to issue in June of this year. Most notably, on March 19, 2015, he sent a letter to the National Governors Association urging the governors of all fifty states not to prepare state plans in response to those regulations. In that letter he laid out what he termed his "serious legal and policy concerns" regarding the EPA proposal. The letter received wide publicity.

Daniel Selmi has written an essay analyzing legal statements made by Senator Mitchell in his letter. The essay points out that the letter erroneously describes both EPA's proposed regulations and the agency's legal authority under the Clean Air Act. It examines how the letter does not fully delineate the consequences that will occur if states follow the letter's advice and refuse to prepare plans that comply with the EPA regulations. Finally, the essay addresses claims in the letter regarding EPA's ability to take control of state energy policy. 


\section{(C) 2015 Sabin Center for Climate Change Law, Columbia Law School}

The Sabin Center for Climate Change Law develops legal techniques to fight climate change, trains law students and lawyers in their use, and provides the legal profession and the public with up-to-date resources on key topics in climate law and regulation. It works closely with the scientists at Columbia University's Earth Institute and with a wide range of governmental, nongovernmental and academic organizations.

Sabin Center for Climate Change Law

Columbia Law School

435 West $116^{\text {th }}$ Street

New York, NY 10027

Tel: +1 (212) 854-3287

Email: columbiaclimate@gmail.com

Web: http://www.ColumbiaClimateLaw.com

Twitter: @ColumbiaClimate

Blog: http://blogs.law.columbia.edu/climatechange

Disclaimer: This paper is the responsibility of The Sabin Center for Climate Change Law alone, and does not reflect the views of Columbia Law School or Columbia University. It is an academic study provided for informational purposes only and does not constitute legal advice. Transmission of the information is not intended to create, and the receipt does not constitute, an attorney-client relationship between sender and receiver. No party should act or rely on any information contained in this White Paper without first seeking the advice of an attorney.

About the author: Daniel Selmi is a Visiting Scholar at the Sabin Center for Climate Change Law, Columbia Law School, and Fritz B. Burns Professor of Real Property Law, Loyola Law School, Los Angeles. Professor Selmi can be contacted via email, dan.selmi@lls.edu. 


\title{
AN ANALYSIS OF SENATOR MCCONNELL'S LETTER URGING STATES NOT TO COMPLY WITH EPA'S CLEAN POWER PLAN
}

\author{
Daniel Selmi
}

On March 19, 2015, Senator Mitch McConnell sent a widely publicized letter to the National Governors Association regarding the Environmental Protection Agency's (EPA's) proposed regulations on carbon emissions from existing power plants. ${ }^{1}$ The letter urged states not to submit plans complying with those upcoming regulations, which EPA will finalize this summer. The press reported Senator McConnell's letter as laying out a "legal blueprint" supporting his position. ${ }^{2}$

This essay addresses the legal issues raised by Senator McConnell's letter. It concludes that the letter contains certain erroneous assertions and omits important considerations.

Statement \#1: “[The] proposed 'Clean Power Plan...would require states to dramatically restructure their electricity systems based on the EPA's view of how electricity should be produced and used in each state." 3

Response: EPA has proposed a single, binding "emission guideline" for carbon emissions from existing power plants in each state. ${ }^{4}$ Under Section 111 of the Clean Air Act, states then prepare plans to meet these guidelines. In proposing the guidelines, EPA considered various methods that states could implement to reduce carbon emissions, including reducing demand and employing alternative sources of energy. These methods are widely used today.

\footnotetext{
${ }^{1}$ Letter, Senator Mitch McConnell to National Governors Association ("NGA Letter") (Mar. 19, 2015), http://www.mcconnell.senate.gov/public/index.cfm?p=newsletters\&ContentRecord_id=d57eba06-0718-4a228f59-1e610793a2a3\&ContentType_id=9b9b3f28-5479-468a-a86b-10c747f4ead7\&Group_id=2085dee5-c3114812-8bea-2dad42782cd4.

2 Coral Davenport, McConnell Urges States to Help Thwart Obama 'War on Coal,' N.Y. Times (Mar. 19, 2015) 1, http://www.nytimes.com/2015/03/20/us/politics/mitch-mcconnell-urges-states-to-help-thwart-obamas-waron-coal.html?_r=0 (Senator McConnell "has taken the unusual step of reaching out to governors with a legal blueprint for them to follow to stop the rules in their states.")

${ }^{3}$ NGA Letter, supra note 1 , at 1.

4 Environmental Protection Agency, Carbon Pollution Emission Guidelines for Existing Stationary Sources: Electric Utility Generating Units, 79 Fed. Reg. 34830, 34895 (June 8, 2014).
} 
EPA's proposed rules do not tell states how they must meet the emission guideline or how they must produce electricity. The proposal expressly declares that "it does not prescribe how a state should meet its goal." ${ }^{5}$ It goes on: "Each state will have the flexibility to design a program to meet its goal in a manner that reflects its particular circumstances and energy and environmental policy objectives." 6 States may pursue compliance alone or through multi-state plans that may prove more cost effective and flexible.

Moreover, all states will not have to "dramatically restructure their electricity systems," as Senator McConnell states. Current programs in some states may meet or come close to meeting the EPA emission guidelines. ${ }^{7}$ Other states will have to take additional steps, but most will be able to build on existing policies and programs, such as integrated resource planning requirements and programs to support renewable energy. Furthermore, in proposing the emission guidelines, EPA took into account that some states were currently more dependent on coal-fired power than other states. ${ }^{8}$ So the conclusion that the EPA proposal will uniformly impose a "dramatic restructuring" of electricity systems on all states is highly exaggerated.

Finally, many coal-fired power plants used in the United States are old and will be retired regardless of the proposed rule. ${ }^{9}$ Indeed, regulators in Senator McConnell's home state of Kentucky believe that the state can meet its proposed emission guideline through already

${ }^{5} \mathrm{Id}$. at 34833 (emphasis added).

${ }^{6} \mathrm{Id}$.

7 See National Assn. of State Energy Officials, Incorporating Energy Efficiency and Renewable Energy Policies into Section Greenhouse Gas Compliance Plans (Feb. 2015), http://111d.naseo.org/Data/Sites/5/media/documents/2015-05incorporatingeeandrepoliciesinto111dplans.pdf (finding that Minnesota is "in a good position to comply with a future carbon reduction goal" and Pennsylvania "also appears well positioned to comply with EPA's proposed rule").

8 Carbon Pollution Emission Guidelines, supra note 4, at 34900 ("The agency also anticipates-and supportsstates' commitments to a wide range of policy preferences that could encompass those of states like Kentucky, West Virginia and Wyoming seeking to continue to feature significant reliance on coal-based generation ...").

${ }^{9} \mathrm{Id}$. at 34833-34 ("In 2025, the average age of the coal-fired generating fleet is projected to be 49 years old, and 20 percent of units would be more than 60 years old if they remained in operation at that time.") 
scheduled retirements of coal-fired power plants. ${ }^{10}$ At least some of these retirements will occur before 2030, the date for final compliance with the emission guideline. ${ }^{11}$

Statement \#2: Senator McConnell cites the four "building blocks" that EPA lays out in its proposed rules for reducing carbon emissions. ${ }^{12}$ He then concludes that "[EPA's] authority under the Clean Air Act extends only to the first building block related to source specific energy efficiency upgrades."13

10 Jean Chemnick, Ky. regulators walk tightrope on Clean Power Plan, Greenwire (Mar. 4, 2015), http://www.eenews.net/stories/1060014457:

Kentucky regulators say they've figured out how they might write an implementation plan for the U.S. EPA Clean Power Plan without violating a state law that severely limits their options.

The Energy and Environment Cabinet hopes to avoid having EPA impose an implementation plan for curbing carbon dioxide emissions with a strategy that relies on retirements of coal-fired power plants that were already planned for the next 15 years.

The agency says those plant shutdowns could generate enough emission reductions to let Kentucky meet its 2030 EPA target.

11 The proposed rules do call for an interim level of reductions to be met in 2020. Carbon Pollution Emission Guidelines, supra note 4, at 34837. EPA, however, has indicated that it is seriously considering whether to modify that requirement. See Valerie Volcovici, U.S. EPA chief hints at softening carbon rule interim timeline, Reuters (Feb. 17, 2015), idUSL1NOVR2ES20150218 ("EPA Administrator Gina McCarthy told an audience of state utility regulators meeting in Washington that she was giving them a 'big hint' the agency may loosen the interim targets set in its proposed rule for existing power plants, under which each state would need to show an assigned average emission reduction between 2020 and 2029.").

12 EPA's proposed rules identify four "building blocks" for constructing strategies to reduce $\mathrm{CO}_{2}$ emissions:

1. Reducing the carbon intensity of generation at individual affected EGUs [Electric Generating Units] through heat rate improvements.

2. Reducing emissions from the most carbon-intensive affected EGUs in the amount that results from substituting generation at those EGUs with generation from less carbon-intensive affected EGUs (including NGCC [Natural Gas Combined Cycle] units under construction).

3. Reducing emissions from affected EGUs in the amount that results from substituting generation at those EGUs with expanded low- or zero-carbon generation.

4. Reducing emissions from affected EGUs in the amount that results from the use of demand-side energy efficiency that reduces the amount of generation required.

Carbon Pollution Emission Guidelines, supra note 4, at 34836.

${ }^{13}$ NGA Letter, supra note 1 , at 1. 
Response: Under Section 111(d) of the Clean Air Act, states establish "standards of performance" for emissions of carbon dioxide from power plants. ${ }^{14}$ The statute defines "standard of performance" as "a standard for emissions of air pollutants which reflects the degree of emission limitation achievable through the application of the best system of emission reduction ...."15 The statute thus directs consideration of a "system" of emission reduction, a word that the Clean Air Act does not define.

EPA has proposed to give "system" its plain meaning as defined in the Oxford Dictionary of English: "a set of things working together as part of a mechanism or interconnecting network; a complex whole."16 Thus, EPA interprets "system" to mean the "interconnected nature of the electricity generating system"17 and to encompass the "four building blocks" as methods by which carbon emissions may be reduced. ${ }^{18}$ These include the immediate source of the emissions--the power plant-as well as other places in the electric system where states' actions could reduce carbon emissions. ${ }^{19}$ EPA has previously issued regulations under Section 111 that encompass such "beyond the powerplant fenceline" measures. ${ }^{20}$

1442 U.S.C. § 7411(d)(1). These "standards of performance" must attain the "emission guideline" established by EPA - the maximum emissions of carbon dioxide from existing power plants in each state.

${ }^{15}$ Id. § 7411(a)(1) (emphasis added).

${ }^{16}$ Environmental Protection Agency, Legal Memorandum for Proposed Carbon Pollution Emission Guidelines for Existing Electric Utility Generating Units, 36, http://www2.epa.gov/sites/production/files/201406/documents/20140602-legal-memorandum.pdf (citing Oxford Dictionary of English (3rd ed.) (published 2010, online version 2013)).

17 Id. at 41 .

${ }^{18}$ Id. at $41-42$.

${ }^{19} \mathrm{Id}$. at 48 :

The fact that $\mathrm{CO}_{2}$ becomes well-mixed in the atmosphere means that $\mathrm{CO}_{2}$ emissions may be reduced anywhere within the electricity grid and still achieve the intended climate benefits. This allows the EPA to determine that a system is the "best" system based on the total emission reductions the system would achieve, rather than basing the determination on the emissions reductions achieved at each individual affected source.

${ }^{20}$ See 64 C.F.R. $\S \S 60.33 b(d)(1)$-(2) (for large municipal waste combustors, state plans may authorize facilities to comply by averaging the emissions rates of several facilities within a state and by trading nitrogen dioxide emission credits); 40 C.F.R. § 60.35e and 40 C.F.R. Part 60, Subpart DDDD (requiring waste incineration facility sources to implement "waste management" plans to reduce the amount of waste that is combusted). 
Opponents of the Clean Power Plan dispute this interpretation. But the Clean Air Act does not define the word "system," and its dictionary definition supports the EPA position. Moreover, it is a bedrock principle of administrative law that, if a statutory term is ambiguous, EPA's interpretation of that term will be upheld if reasonable. ${ }^{21}$ Here, given that the dictionary definition of "system" encompasses the interconnected nature of the electricity system extending beyond power plants, the interpretation is reasonable.

Statement \#3: "In other words, the EPA is attempting to compel states to do more themselves than what the agency would be authorized to do on its own..."22

Response: EPA's rules do not "attempt[] to compel" states to act or order states to comply with their content. Under the Clean Air $\mathrm{Act}^{23}$ and precedents construing the Tenth Amendment to the Constitution, ${ }^{24}$ a state can refuse to prepare a plan under the Act, and EPA cannot demand that it do so. So the choice whether to prepare a plan is up to the state.

${ }^{21}$ Chevron U.S.A., Inc. v. Natural Resources Def. Council, 467 U.S. 837, 845 (1984) ("Once it [the court] determined, after its own examination of the legislation, that Congress did not actually have an intent regarding the applicability of the bubble concept to the permit program, the question before it was not whether in its view the concept is 'inappropriate' in the general context of a program designed to improve air quality, but whether the Administrator's view that it is appropriate in the context of this particular program is a reasonable one.").

22 NGA Letter, supra note 1 , at 1.

${ }^{23}$ District of Columbia v. Train, 521 F.2d 971, 983-84 (D.C. Cir. 1975) (citing Plan for Arcadia v Anita Associates, 379 F. Supp. 311 (C.D. Cal. 1973), aff'd 501 F.2d 390 (9th Cir. 1974)).

${ }^{24}$ See New York v. United States, 505 U.S. 144, 175-76 (1992):

Either type of federal action [in the Low-Level Radioactive Waste Policy Act] would "commandeer" state governments into the service of federal regulatory purposes, and would for this reason be inconsistent with the Constitution's division of authority between federal and state governments. On the other hand, the second alternative held out to state governments-regulating pursuant to Congress' direction-would, standing alone, present a simple command to state governments to implement legislation enacted by Congress. As we have seen, the Constitution does not empower Congress to subject state governments to this type of instruction. 
If the state refuses, EPA then must adopt a so-called "federal implementation plan" (FIP) for that state. ${ }^{25}$ But that plan also will not "compel states" to act. Instead, it will require actions by EPA.

Statement \#4: "As Professor [Laurence] Tribe has noted, the Clean Air Act not only fails to authorize EPA's plan, it forbids it."26

Response: Senator McConnell presumably refers to Professor Tribe's recent testimony before a Congressional subcommittee. ${ }^{27}$ States should closely consider three factors before accepting Senator McConnell's conclusion.

First, while Professor Tribe labels his submission as testimony, the submission excoriates EPA for acting illegally in numerous ways and employs extreme language castigating the agency. States should decide for themselves if the document reads like an impartial analysis of the legal issues or like a brief strongly arguing positions from a client's particular viewpoint. ${ }^{28}$

Second, in determining how much weight to give the testimony, states should look carefully at the constitutional analysis in it. Other academics have responded to Professor Tribe's claim that the regulations will violate the Tenth Amendment or the separation of powers doctrine. ${ }^{29}$ But states should especially consider the claim that EPA's proposal raises serious Fifth

2542 U.S.C. § 7411(d)(2) (Administrator has "same authority" to prescribe a plan for states who fail to submit satisfactory plans as she does under Section 110.) See Coalition for Clean Air v. Southern California Edison Co., 971 F.2d 219, 224 (9th Cir. 1992) (Under Section 110 "EPA must promulgate a FIP within two years of such disapproval. ..").

${ }^{26}$ NGA Letter, supra note 1 , at 1.

${ }^{27}$ Testimony of Laurence H. Tribe, EPA's Proposed 111(d) Rule for Existing Power Plants: Legal and Cost Issues, Subcommittee on Energy and Power, House Committee on Energy and Commerce (Mar. 17, 2015), http://docs.house.gov/meetings/IF/IF03/20150317/103073/HHRG-114-IF03-Wstate-TribeL-20150317-U1.pdf.

${ }^{28}$ EPA disputes the positions in this testimony, and the issues are now being initially litigated in the U.S. Court of Appeals for the District of Columbia Circuit. Murray Energy v. EPA, U.S. Court of Appeals for the District of Columbia Circuit Nos. 14-1112, 14-1151.

${ }^{29}$ See, e.g., Michael Gerrard, The Constitutional foundation for the Clean Power Plan, The Hill (Mar. 19, 2015) http://thehill.com/blogs/congress-blog/energy-environment/236185-the-constitutional-foundation-for-theclean-power-plan; Testimony of Richard Revesz Before the House Subcommittee on Energy and Power, House Committee on Energy and Commerce (Mar. 17, 2015), http://docs.house.gov/meetings/IF/IF03/20150317/103073/HHRG-114-IF03-Wstate-ReveszR-20150317.pdf;

Jody Freeman and Richard J. Lazarus, Larry Tribe and Mitch McConnell's Flagrant Constitutional Error, Politico (Mar. 25, 2015) http://www.politico.com/magazine/story/2015/03/epa-climate-rules-mitch-mcconnell- 
Amendment questions. States are, of course, very familiar with the features of Fifth Amendment law and thus are in a particularly good position to evaluate this argument.

Two premises for the claim of a Fifth Amendment violation are erroneous. First, the testimony states that the Clean Power Plan is regulating "a select few" businesses and singling out "a handful of emitters." 30 But, according to the Edison Electric Institute, the electric power industry is an $\$ 840$ billion industry that represents approximately 3 percent of real gross domestic project. ${ }^{31}$ In 2012 the combustion of fossil fuels to generate electric power accounted for almost 39 percent of all energy related $\mathrm{CO} 2$ emissions. $^{32}$

Second, the testimony states that the Clean Power Plan presents a situation of "regulating an entity out of existence...." However, according to EPA, under the Clean Power Act coal-fired power plants will continue to generate approximately $30 \%$ of the nation's power. ${ }^{33}$

Overall, the testimony concludes that "EPA's singling out of a mere handful of emitters and drastically curtailing their use of the property" requires compensation under the Fifth Amendment. ${ }^{34}$ But if that position in the statement correctly states the law, the general scheme that environmental law uses to regulate pollution would violate the Fifth Amendment. For almost half a century, the federal Clean Air and Clean Water Acts have operated by "singling out" categories of industry and regulating the various pollutants that they emit or discharge. ${ }^{35}$ Courts have routinely upheld such regulations. ${ }^{36}$

116399.html\#.VSatV010zcs. See also: Is the President's Climate Plan Unconstitutional? Harvard Law Today (Mar. 18, 2015), http://today.law.harvard.edu/is-the-presidents-climate-plan-unconstitutional/. The two sides have critiqued each others' position in the Harvard Daily. See http://today.law.harvard.edu/jody-freemanrichard-lazarus-respond-professor-tribes-reply/.

${ }^{30}$ Tribe Testimony, supra note $27,28,31$. See also id.at 29 ("a fraction of the emitters.").

${ }^{31}$ Edison Electric Institute, Key Facts about the Electric Power Industry, ii, 1, http://www.eei.org/resourcesandmedia/key-facts/Documents/KeyFacts.pdf (industry size measured as of December 31, 2012).

32 Carbon Emission Guidelines, supra note 4, at 34843.

${ }^{33} I d$. at 34832. (In 2030 "coal and natural gas would remain the two leading sources of electricity generation in the U.S., with each providing more than 30 percent of the projected generation. ..").

34 Tribe Testimony, supra note 27, at 31.

35 See 33 U.S.C. $\S 1311$ (... for pollutants identified in subparagraphs (C), (D), and (F) of this paragraph, effluent limitations for categories and classes of point sources, other than publicly owned treatment works, 
Finally, the testimony cites no case law that would find a taking in a situation even remotely comparable to the proposed rules. ${ }^{37}$

Statement \#5: Senator McConnell cites the Supreme Court's 2014 decision in Utility Air $\underline{\text { Regulatory Group v. EPA }}{ }^{38}$ as defining the limits of EPA's regulatory powers and concludes that "[t]his rule clearly meets that definition." 39

Response: In Utility Air Regulatory Group, the Supreme Court upheld EPA's authority to regulate greenhouse gas emissions from sources otherwise subject to regulation under the Clean Air Act's "Prevention of Significant Deterioration" program. ${ }^{40}$ As the Court noted, these sources “account for roughly 83\% of American stationary-source greenhouse-gas emissions . . ."41 This was the third case in which the Supreme Court has upheld EPA's authority to regulate greenhouse gases. $^{42}$

which (i) shall require application of the best available technology economically achievable for such category or class...").

36 See, e.g., DuPont v Train, 430 U.S. 112, 134 (1977) ("[W]e hold that EPA has the authority to issue regulations setting forth uniform effluent limitations for categories of plants."); Reynolds Metal Co. v. U.S. E.P.A., 760 F.2d 549 (4th Cir. 1985) (upholding effluent limitations set for the category comprised of the canmaking industry); Allied Local and Regional Mfrs. Caucus v. U.S. E.P.A., 215 F.3d 61 (D.C. Cir. 2000) (upholding regulations limiting volatile organic compounds in architectural coatings such as paints).

${ }^{37}$ Black letter Fifth Amendment law holds that a per se taking occurs only if the government regulation results in a permanent physical invasion of property or "completely deprive[s] an owner of "all economically beneficial us[e]' of her property." Lingle v. Chevron U.S.A. Inc., 544 U.S. 528, 538 (2005) (citing Lucas v. South Carolina Coastal Council, 505 U.S. 1003,1019 (1992).) Otherwise, courts use the well-known balancing test set forth in the Supreme Court's 1978 decision, Penn Central Transp. Co. v. New York City. 438 U.S. 104, 124 (1978). Under that test, the court looks at a variety of factors in addition to the expectations of the regulated party. Lingle, 544 U.S. at 538-39). It is very unlikely that the power regulations would take the property of power companies under this test.

${ }^{38}$ _ U.S. __ 134 S. Ct. 2427 (2014).

${ }^{39}$ NGA Letter, supra note 1, at 1-2.

40134 S. Ct. at 2449.

${ }^{41} \mathrm{Id}$. at 2438-39. These are called the "anyway" sources, "those that would need permits based on their emissions of more conventional pollutants (such as particular matter). .." Id. at 2447.

${ }^{42}$ See Massachusetts V. E.P.A., 549 U.S. 497, 528 (2007) ("On the merits, the first question is whether $\S$ 202(a)(1) of the Clean Air Act authorizes EPA to regulate greenhouse gas emissions from new motor vehicles in the event that it forms a "judgment" that such emissions contribute to climate change. We have little trouble concluding that it does. ..."); Am. Elec. Power Co. v. Connecticut, 131 S. Ct. 2527, 2537 (2011) (“We hold that the Clean Air Act and the EPA actions it authorizes displace any federal common law right to seek 
Senator McConnell twice quotes from a part of the Utility Air opinion in which the Court rejects one EPA argument. Here is the entire quote from that part of the opinion:

EPA's interpretation is also unreasonable because it would bring about an enormous and transformative expansion in EPA's regulatory authority without clear congressional authorization. When an agency claims to discover in a long-extant statute an unheralded power to regulate "a significant portion of the American economy," Brown $\mathcal{E}$ Williamson, 529 U.S., at 159, 120 S. Ct. 1291, we typically greet its announcement with a measure of skepticism. We expect Congress to speak clearly if it wishes to assign to an agency decisions of vast "economic and political significance." 43

In the remainder of this paragraph of the opinion, however, the Court explains its concern:

The power to require permits for the construction and modification of tens of thousands, and the operation of millions, of small sources nationwide falls comfortably within the class of authorizations that we have been reluctant to read into ambiguous statutory text. Moreover, in EPA's assertion of that authority, we confront a singular situation: an agency laying claim to extravagant statutory power over the national economy while at the same time strenuously asserting that the authority claimed would render the statute "unrecognizable to the Congress that designed" it.... ${ }^{44}$

EPA's proposed power rules do not claim authority to regulate on this type of scale or render the statute unrecognizable. Rather, the proposed rules will regulate one class of sources only, existing fossil fuel-fired electric generating units, a class which includes 518 coal-fired power plants as of 2013. ${ }^{45}$ This class of electric generating units has been consistently regulated in the past

abatement of carbon-dioxide emissions from fossil-fuel fired power plants. Massachusetts made plain that emissions of carbon dioxide qualify as air pollution subject to regulation under the Act. 549 U.S. at 528-529, 127 S.Ct. 1438. And we think it equally plain that the Act 'speaks directly' to emissions of carbon dioxide from the defendants' plants. ..").

${ }^{43}$ Util. Air Regulatory Grp. 134 S. Ct. at 2444.

${ }^{44} I d$. at 2427.

45 U.S. Energy Information Administration, Electric Power Annual Report (Mar. 23, 2015), Table 4.1 ("Count of Electric Power Industry Power Plants, by Sector, by Predominant Energy Sources within Plant, 2003 through 2013), found at http://www.eia.gov/electricity/annual/html/epa_04_01.html. 
for other emissions. ${ }^{46}$ The new rules will simply add carbon emissions to the list of pollutants regulated at these plants.

Statement \#6. "A recent study by National Economic Research Associates (NERA) found that under the EPA's proposed plan, double-digit electricity rate increases are projected for 43 states." 47

Response: Two points about the NERA study ${ }^{48}$ should be noted. First, various industry groups, including coal companies, commissioned the NERA study to evaluate the costs of the Clean Power Plan. ${ }^{49}$ Of course, the fact that industry groups funded the study no more disqualifies it from playing a role in the regulatory debate than it does when other groups, such as environmental organizations, fund studies. ${ }^{50}$ But the study is just that-one calculation of costs

${ }^{46}$ See, e.g., 40 C.F.R. $§ 52.800(c)(159)$, approving additions to Indiana's state implementation plan:

On January 31, 2003, Indiana submitted revised particulate matter regulations for Richmond Power and Light Company's coal burning power plant in Wayne County, Indiana. The submission amends 326 IAC 6-1-14. The revisions make the long-term emission limits consistent with the short-term limits approved by EPA on April 9, 1996. The new limits are 320 tons per years for boiler number 1 and 700 tons per years for boiler number 2 .

${ }^{47}$ NGA Letter, supra note 1 , at 2.

${ }^{48}$ NERA Economic Consulting, Potential Energy Impacts of the EPA Proposed Clean Power Plan (Oct. 2014), http://www.nera.com/content/dam/nera/publications/2014/NERA_ACCCE_CPP_Final_10.17.2014.pdf.

${ }^{49}$ The study states that it was prepared for American Coalition for Clean Coal Electricity, American Fuel \& Petrochemical Manufacturers, Association of American Railroads, American Farm Bureau Federation, Electric Reliability Coordinating Council, Consumer Energy Alliance, and National Mining Association. Potential Energy Impacts, supra note 48, cover. As the Washington Post's Fact-checker concluded when analyzing a statement by Senator James Inhofe citing the same study:

His claim that electricity prices will increase by double digits comes from a study commissioned by industry groups that oppose the Clean Power Plan. But the claim is misleading. His estimates are on the high end of a range of cost impacts, which are mere projections at this point. [Update: Initially, we concluded Inhofe assumed the worst-case scenario, but researchers of the study pointed out to us there are higher estimates in the report.] A lot of the costs can be driven down by state, local and regional policymakers, and some of them already are working with the EPA to figure out costeffective plans. This is a highly technical topic with many caveats yet to be sorted out.

Michelle Ye Hee Lee, Inhofe's Misleading Statements on Carbon Emissions Rule, The Washington Post (Mar. 13, 2015), http://www.washingtonpost.com/blogs/fact-checker/wp/2015/03/13/inhofes-misleading-statementson-carbon-emissions-rule.

50 See, e.g., Union of Concerned Scientists, Strengthening the EPA's Clean Power Plan (Oct. 2014) http://www.ucsusa.org/sites/default/files/attach/2014/10/Strengthening-the-EPA-Clean-Power-Plan.pdf 
commissioned by industry. It is certainly not the final or definitive word on costs, especially when EPA has not yet completed its rulemaking.

Additionally, the NERA analysis concludes that the costs of complying with the Clean Power Plan are substantially lower if states use all four "building blocks" in EPA's proposal than if they just use the first two. ${ }^{51}$ Indeed, that was precisely EPA's point in proposing the building blocks: to afford states increased flexibility in designing cost-effective pathways to reducing carbon emissions. ${ }^{52}$ Yet Senator McConnell argues that states should reject that cheaper alternative and refuse any response to the upcoming EPA rules. If states follow that advice, the Clean Air Act requires EPA to impose a federal implementation plan in the state, and the likelihood is that state costs under that plan will be higher than if the state used the four building blocks. ${ }^{53}$

Statement \#7: "EPA's stated rationale for attempting to shut down America's coal-fired power plants is to combat climate change." 54

(concluding that EPA could nearly double the amount of cost-effective renewable energy in the state targets included in EPA's draft rules); Natural Resources Defense Council, Closing the Power Plant Carbon Pollution Loophole: Smart Ways the Clean Air Act Can Clean Up America's Biggest Climate Polluters (Mar. 2013) http://www.nrdc.org/air/pollution-standards/files/pollution-standards-report.pdf (analyzing a proposal similar to that ultimately proposed by EPA). See also The Analysis Group, EPA's Clean Power Plan: States' Tools for Reducing Costs and Increasing Benefits to Consumers (July 2014), 1 http://www.analysisgroup.com/uploadedFiles/Publishing/Articles/Analysis_Group_EPA_Clean_Power_Pla n_Report.pdf ("[W]e believe that the impacts on electricity rates from well-designed CO2 pollution control programs will be modest in the near term and can be accompanied by long-term benefits in the form of lower electricity bills and positive economic value to state and regional economies. . .").

${ }^{51}$ Potential Energy Impacts, supra note 48, at S-7 ("The net cost of the State Constrained (BB1-2) scenariowhich excludes end-use energy efficiency, renewables and additional nuclear energy from compliance-is substantially greater than the State Unconstrained (BB1-4) scenario.").

52 See Carbon Pollution Emission Guidelines, supra note 4, at 34836:

[T] ]he EPA believes that the diverse range of measures encompassed in the four building blocks allows states and sources to take full advantage of the inherent flexibility of the current regionally interconnected and integrated electricity system so as to achieve the $\mathrm{CO}_{2}$ goals while continuing to meet the demand for electricity services in a reliable and affordable manner.

${ }^{53}$ See Brian Potts and David Zoppo, States: "Just Say No" to Senator McConnell's Costly Climate Plan," Real Clear Energy (Mar. 10, 2015) http://www.realclearenergy.org/articles/2015/03/10/states just say no to senator mcconnells costly climat e plan 108331.html (discussing how states would fare worse economically under a federal implementation plan).

${ }^{54}$ NGA Letter, supra note 1 , at 2. 
Response: EPA's Clean Power Plan does not state that it is "attempting to shut down America's coal-fired power plants." Rather, its expressed goal is to reduce emissions of carbon dioxide from existing power plants by $30 \%$ by the year 2030.55 EPA predicts that under the Clean Power Plan, coal and gas will remain the two leading fuel sources for production of electricity. ${ }^{56}$

Additionally, Senator McConnell omits the reason why EPA has targeted emissions from electric generating units. These units are the largest emitters of greenhouse gases, primarily in the form of carbon dioxide, among all sources in the United States. ${ }^{57}$

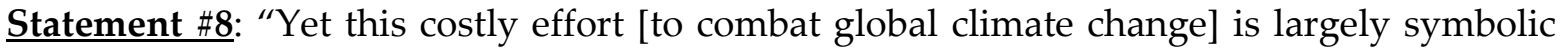
unless and until other major nations impose similar requirements on their own economies." 58 The proposed plan "will not seriously address the global environmental concerns that are frequently raised to justify it." 59

Response: The proposed regulations will result in a 30 percent decrease in carbon dioxide emissions from power plants, a very large contributor to global warming in the United States. ${ }^{60}$ Senator McConnell never explains why this large reduction is only "largely symbolic" and would not "seriously address" global climate concerns.

Senator McConnell implies that states should wait until some future time when other nations act. ${ }^{61}$ At the same time, however, Senator McConnell is working to ensure that no such agreement takes place. One of his purposes in urging state inaction is to undercut the ongoing

${ }_{55}$ Carbon Pollution Emission Guidelines, supra note 4, at 34832 ("Nationwide, by 2030, this rule would achieve $\mathrm{CO} 2$ emission reductions from the power sector of approximately 30 percent from $\mathrm{CO} 2$ emission levels in 2005...").

${ }^{56} I d$. ("[C]oal and natural gas would remain the two leading sources of electricity generation in the U.S., with each providing more than $30 \%$ of the projected generation. ..").

${ }^{57} \mathrm{Id}$. at 34833 .

58 NGA Letter, supra note 1 , at 2.

${ }^{59} \mathrm{Id}$. at 3.

${ }^{60}$ Carbon Emission Guidelines, supra note 4, at 34832.

${ }^{61}$ Senator McConnell is undoubtedly aware of, but presumably dismisses, China's historic announcement that it would begin reducing emissions from its coal-fired power plants. See, e.g., Matt Yoye and Holly Yan, U.S. and China Reach Historic Climate change Deal, Vow to Cut Emissions, CNN (Nov. 12, 2014) http://www.cnn.com/2014/11/12/world/us-china-climate-change-agreement/index.html 
efforts of the Obama Administration to broker an agreement at the upcoming United Nations Climate Change Conference in Paris. As The New York Times reported in its article on Senator McConnell's letter to the State Governors, "In addition to stopping state-level enactment of the climate rules, Mr. McConnell's strategy is intended to undercut Mr. Obama's position internationally as he tries to negotiate a global climate change treaty to be signed in Paris in December."62

The Clean Power Plan is the centerpiece of the pledges that the United States is making as part of the United Nations climate negotiations. ${ }^{63}$ Without these pledges, it is unlikely that China or other major emitters will make serious pledges of their own. Thus the Clean Power Plan is effectively a prerequisite for the climate change actions of many other countries.

Finally, Senator McConnell has declared that his efforts are intended to protect the coal industry in his home state. ${ }^{64}$

States should consider carefully whether they want to enlist in Senator McConnell's program to oppose all progress in combatting climate change. What Senator McConnell sees as good public policy for Kentucky is quite likely not the best policy choice for other states.

Statement \#9: "EPA's deadlines were very likely designed to force states to develop and submit implementation plans before the courts can decide on the legality of the [Clean Power Plan]."65

${ }^{62}$ McConnell Urges States to Help Thwart, supra note 2.

${ }^{63}$ See Jean Chemnick, U.S. pledges to try for 28\% GHG cut by 2025, Greenwire (Mar. 31, 2015) http://www.eenews.net/greenwire/stories/1060016068:

The Obama administration formally promised the world today that the United States would use laws already on the books to cut greenhouse gases across the economy by at least 26 percent by 2025, and "to make best efforts to reduce its emissions by 28 percent."

$* * *$

The U.S. submission will form the core of its negotiating position during U.N. climate talks in Paris this December, which countries hope will finally produce a global climate agreement.

${ }^{64}$ Joe Gerth, McConnell on Climate Change: "Not a Scientist," The Courier Journal (Oct. 3, 2014), http://www.courier-journal.com/story/news/politics/elections/kentucky/2014/10/02/mcconnell-climate-

change-scientist/16600873/ ("When asked what it would take to convince him that climate change is a problem, he demurred and said, "I'm not a scientist, I am interested in protecting Kentucky's economy, I'm interested in having low cost electricity.") 
Response: States have from two to three years to submit final implementation plans, ${ }^{66}$ and they have been on notice of EPA's proposal for an additional year. ${ }^{67}$ Those time periods are not unreasonable. Furthermore, the full implementation of those plans will not occur until well after any litigation is decided.

Statement \#10: "The EPA has no authority to either bring a lawsuit against any state that fails to submit a state plan, or to withhold federal funds from states that decline to submit a plan."68

Response: Senator McConnell is correct that EPA lacks authority to sue a state that fails to submit a state plan. Of course, the agency has never contended in this rulemaking that it possesses this authority.

Whether EPA lacks authority under the Clean Air Act to impose sanctions is not entirely clear. Some have argued that the sanctions authorized by Section 179 of the Clean Air Act apply only to (1) so-called "nonattainment areas" (i.e., areas that have not attained one or more of the national ambient air quality standards), or (2) inadequate plan submittals under Section 110 of the Act (i.e., plans intended to attain the national ambient air quality standards). ${ }^{69}$ Thus, the argument proceeds, the sanctions do not apply to submittals under Section 111. That conclusion seems likely

${ }^{65}$ NGA Letter, supra note 1 , at 2.

${ }^{66}$ Carbon Emission Guidelines, supra note 4, at 34833 ("This proposal also gives states considerable flexibility with respect to the timeframes for plan development and implementation, providing up to two or three years for submission of final plans and providing up to fifteen years for full implementation of all emission reduction measures, after the proposal is finalized. ..").

${ }^{67} I d$. at 34830 (proposed June 18, 2014).

${ }^{68}$ NGA Letter, supra note 1 , at 2.

${ }^{69}$ Peter S. Glaser et al., EPA's Section 111(d) Carbon Rule: What if States Just Said No?, The Federalist Society (Nov. 6, 2014) at 6, http://www.fed-soc.org/publications/detail/epas-section-111d-carbon-rule-what-if-statesjust-said-no (arguing Section 179 "applies only to two types of State plans: (a) 'any implementation plan or plan revision required under this part,' meaning part D of title I of the CAA [i.e. nonattainment areas], and (b) any such plan or plan revision 'required in response to a finding of substantial inadequacy as described in section $7410(\mathrm{k})(5)^{\prime}$ [i.e. for state implementation plans for criteria pollutants.]" See also Doug Obey, McConnell Targets Highway Fund Tool for ESPS Despite Lack of EPA Power, Climate Daily News (Mar. 26, 2015 ("'[McConnell] is tilting at a non-existent windmill,' says one environmentalist, citing a 'strong argument' that the air act only allows EPA to withhold highway funds for noncompliance with a national ambient air quality standard (NAAQS) - not a section 111 rule like the ESPS.") 
to be correct, as the sanctions provisions of the Act are particularly tailored to the nonattainment situation.

On the other hand, Senator McConnell here disagrees with Professor Tribe, who has concluded that sanctions do apply. ${ }^{70}$ An argument can be made that the statute supports this conclusion. ${ }^{71}$

From the state's perspective, however, the legality of withholding highway funds should not be a serious practical consideration for three reasons. First, EPA has almost never used this sanction in the past, and its public statements show that it is disinclined to use the sanction here. ${ }^{72}$ Second, the Highway Trust Fund is nearing insolvency, and future highway funding is uncertain. ${ }^{73}$

Third, and most importantly, the Clean Air Act requires EPA to impose a federal implementation plan in place of the plan that the state has refused to submit. ${ }^{74}$ The FIP - not the possibility of sanctions - is by far the most important consequence of a state's failure to submit a plan. As this paper now discusses, Senator McConnell incorrectly dismisses the effects of such a FIP.

${ }^{70}$ Tribe Testimony, supra note 2. The first paragraph of the testimony states that "[n]oncomplying States would face sanctions, including the potential loss of federal highway funds. .."

${ }^{71}$ Section 179(a)(3)(A) of the Clean Air Act authorizes the Administrator to impose sanctions when the Administrator "determines that a State has failed to make any submission as may be required under this chapter..." (Italics added). 42 U.S.C. § 7509(a)(3)(A). Section 111 of the Act is, like Section 179, part of Chapter 85 in Title 42 of the United States Code. Section 111(d)(1) states that each State "shall submit to the Administrator a plan" which establishes standards of performance. 42 U.S.C. $\S 7411(\mathrm{~d})(1)$. Thus, a state choice not to send a plan to EPA could be seen as a "fail[ure] to make [a] submission" under Chapter 85 that triggers the sanctions mechanism.

72 See McConnell Targets Highway Fund Tool, supra note 68 ("EPA Administrator Gina McCarthy at a March 4 Senate hearing downplayed prospects that EPA could threaten to withhold highway funds for noncompliance with the ESPS. She noted that the ESPS is not enforced by a state implementation plan (SIP) in the same way that NAAQS are. ESPS compliance plans "are not a traditional SIP," she said, and "there's other processes to work with states" beyond withholding highway funds.")

${ }^{73}$ See Martin Sullivan, High Hopes for Highway Funding: A Bridge to Nowhere, Barron's (Mar. 4, 2015) http://www.forbes.com/sites/taxanalysts/2015/03/04/high-hopes-for-highway-funding-a-bridge-to-nowhere/ ("Congress must act soon. The highway and transit accounts will reach their minimum prudent balances in May or June. Without replenishment, these accounts would reach absolute zero at about the end of fiscal 2015 (at the end of September).")

${ }^{74} 42$ U.S.C. § 7411(d). 
Statement \#11. "[T]here is serious doubt about whether the EPA has the authority to impose a federal plan that mandates the measures and actions it wants states to undertake, including switching electricity generation away from coal-fired plants and requiring other plants to make up the difference; requiring the construction and use of higher-cost and variable renewable sources; and imposing programs to reduce the use of electricity by residents or businesses. Thus, a federal plan likely would be limited to regulating a power plant itself, such as the efficiency measures under the EPA's building block 1."75

Response: The Clean Air Act does not authorize EPA to order states to implement a FIP, and the Tenth Amendment probably would forbid such an order. The FIP requirements, then, will be imposed on private parties. The issue is what private parties will be subject to the FIP.

Here, some uncertainty exists about the scope of EPA's power to impose a federal implementation plan under Section 111. As discussed above, ${ }^{76}$ this statute defines "standard of performance" to reflect "the best system of emission reduction," 77 a term which EPA has interpreted to include demand reduction and alternative sources of energy. EPA could logically conclude that, because this "best system" authority applies to state plans, it also applies to FIPs imposed in the place of state plans. Under that view, EPA could adopt a FIP that imposes controls only on power plants but, in establishing the level of those controls, takes into account potential demand reductions and alternative sources. ${ }^{78}$

Senator McConnell ignores this possibility - perhaps a likelihood -- that by failing to submit a plan, the state risks stringent, federally imposed controls on the state's power plants. Power companies undoubtedly will greatly dislike both the imposition of that responsibility on them and the potential liability that will arise if the plants fail to meet their federally set emission standards.

${ }^{75}$ NGA Letter, supra note 1 , at 2.

76 See discussion of Statement \#2, supra.

7742 U.S.C. $\S 7411(\mathrm{a})(1)$.

${ }^{78}$ EPA perhaps could also argue that the "best system" language authorizes it to exercise control via permits over these "beyond the fence-line" entities. However, even if EPA theoretically took this position, it is unlikely to attempt any exercise of that power in a FIP. The agency lacks the resources needed to administer such a large-scale program. 
Statement \#12: "[I]t is difficult to see how it [a Federal Implementation Plan] could be any worse than the plan it [EPA] is asking states to impose on themselves."79

Response: From a state's perspective, a federal implementation plan would be worse for a number of reasons. ${ }^{80}$

First, a federal implementation plan is likely to be more expensive than a state plan, as states have more flexibility in designing their plans and more detailed knowledge about how to minimize costs. Second, as discussed above, a FIP adopted by EPA likely will place the entire regulatory burden on power plants, and that burden could be stringent. Third, if EPA imposes a FIP, the state will cede regulatory authority over emissions from its power plants to EPA and lose local control. If a state later changes its mind, it will have to prepare a plan that meets EPA's requirements and then incur delays as EPA undertakes and completes the procedures of approving that plan.

All these are significant consequences. A state can avoid them and control its own regulatory destiny by submitting its own plan.

Statement \#13: "Finally and perhaps most importantly, submitting a plan exposes states to the real danger -- allowing the EPA to wrest control of a state's energy policy if they or any other federal agency becomes dissatisfied with a state's progress in reaching federal emission goals." ${ }^{1}$

Response: The Clean Air Act does not authorize EPA to act because the agency "becomes dissatisfied with a state's progress" in implementing its plan. EPA can act only if, after a state submits a plan that EPA approves, the state then fails to carry out its plan. ${ }^{82}$ In that instance EPA then must first give notice to the state and afford it the opportunity to cure the deficiency. ${ }^{83}$ Further, in this situation EPA cannot "wrest control of a state's energy policy" from the state.

${ }^{79}$ NGA Letter, supra note 1 , at 3.

80 See Daniel P. Selmi, States Should Think Twice about Refusing Any Response to EPA's Clean Power Rules (March 2015), http://blogs.law.columbia.edu/climatechange/2015/03/03/states-should-think-twice-beforerefusing-any-response-to-epas-clean-power-rules/.

${ }^{81}$ NGA Letter, supra note 1 , at 3.

82 See 42 U.S.C. § 7413(a)(2) ("State failure to enforce SIP or permit program").

${ }^{83} I d$. $\S 7413(a)(1)$, (2) (thirty day notice requirement (and up to 90 days in some instances) before EPA may use enforcement options). 
Instead, it can only bring an action to enforce the plan to which the state had previously committed.

Senator McConnell's letter also declares that EPA can act if "any other federal agency" becomes dissatisfied with a state's progress. But the Clean Air Act does not authorize EPA to take enforcement action because a different federal agency decides that it is "dissatisfied" by what a state has done.

In short, if a state submits a plan that EPA has approved, it need worry only if it then refuses to carry out the plan. That scenario is unlikely to occur if states submit plans that are realistic and optimize the mix of measures for state compliance. The loss of control is much more likely to occur, and the risk of federal intervention is much greater, if a state refuses to submit a plan to EPA.

$\underline{\text { Statement \#14. }}$.[D]eclining to go along with the administration's legally dubious plan will give the other two branches of government time to address the proposal and will not put your state at risk in the interim." 84

Response: States will have two to three years to prepare their plans and up to 15 years to implement them. But if they put off preparing plans, the likelihood is that they will not be able to comply with the rules in time, and EPA will impose a federal implementation plan in that state. As discussed above, the state will thus cede to EPA regulatory control over emissions from power plants in the state, and the state will be in a worse position than if it had submitted a plan.

Furthermore, when Senator McConnell suggests that state refusals will give Congress time to "address the proposal," he must be referring to his position that Congress should outlaw the Clean Power Plan. States can determine whether such Congressional action, which would require President Obama's signature, is likely, and whether following Senator McConnell's lead in this situation will provide the best energy outcome for their residents.

${ }^{84}$ NGA Letter, supra note 1 , at 3. 